\title{
SISTEM INFORMASI PENJUALAN PADA TOKO FAISAL ELEKTRONIK 2 INDRAGIRI HILIR BERBASIS WEB
}

\author{
'M. Syariat, ${ }^{2}$ Samsudin \\ 1,2 Program Studi Sistem Informasi, Fakultas Teknik dan Ilmu Komputer \\ Universitas Islam Indragiri (UNISI) \\ Jl. Provinsi , Parit 1 Tembilahan Hulu, Tembilahan, Riau \\ Email:m.syariat1991@gmail.com, samsudin.as.ad.@gmail.com
}

\begin{abstract}
ABSTRAK
Toko Faisal Elekonik 2 tempat saya melaksanakan Penelitian masih menggunakan sistem manual untuk penjualan dan pencatan. Metode penyelasaian masalah yaitu: menggunakan metode pengumpulan data, Observasi, Wawancara, Literatur. Setelah mengembangkan pada toko faisal elektronik 2, maka didapatkan hasil pengujian sistem yang dilakukan dengan metode black box dan white box, yang berguna untuk menguji kelayakan sistem yang telah dibuat, berdasarkan dari pengujian blackbox dan whitebox yang telah dilakukan terhadap sistem yang baru, dapat disimpulkan bahwa sistem yang telah dibuat tersebut sudah berjalan. Dengan adanya sistem ini mempermudahkan pekerjaan dapat selesai dengan cepat dan hasil yang sangat memuaskan. Sehubungan dengan hal itu, dibutuhkan web pada Toko Faisal Elekonik 2 untuk menyampaikan informasi ke calon pelanggan tentang profil Toko Faisal Elekonik 2, fasilitas,dan serta membuat para calon pelanggan Toko Faisal Elekonik 2 mudah untuk mengakses informasi-informasi dan informasi tentang barang-barang Elektronik yang ada di Toko Faisal Elekonik 2. Dengan itu para calon pelanggan tertarik untuk membeli kompnenen Elektronik yang ada di Toko Faisal Elekonik 2.
\end{abstract}

Kata Kunci: Web, Uml, Black box, White box.

\section{PENDAHULUAN}

Teknologi telah banyak membantu manusia dalam mengerjakan pekerjaan mereka sehingga menjadi lebih mudah, cepat dan hasil yang memuaskan. Salah satu teknologi itu adalah komputer. Dalam sebuah instansi saat ini, komputer merupakan sebuah alat atau sarana yang sangat membantu dalam menyelesaikan pekerjaan perusahaan dibidangnya masing-masing. Hal ini tidak dapat dipungkiri lagi, karena dengan menggunakan komputer pekerjaan kantor dapat diselesaikan dengan cepat dan hasil yang sangat memuaskan. Pada saat ini, teknologi berkembang dengan sangat pesat. Terlebih lagi dibidang komputerisasi. Orang secara personal ataupun instansi sudah mulai menerapkan sistem komputerisasi diberbagai bidang. Sehingga tidaklah berlebihan jika dikatakan saat ini adalah zaman komputer. Tidak berlebihan pula jika saat ini disebut orang suatu instansi akan mati tanpa komputer. Hal ini dikarenakan banyaknya kemudahan yang ditawarkan oleh sistem komputer dan internet pada manusia. Berkembangnya pengguna internet pada saat ini mendukung Toko Faisal Elektronik 2 mengembangkan wilayah pemasaran dan layanan terhadap pelanggan. Banyak yang perlu dilakukan untuk mendukung hal tersebut, dengan membuat sistem informasi Penjualan. Hal ini disebabkan banyaknya kemudahan dari sebuah sistem komputer dan memudahkan manusia menggunakan internet. Internet dibutuhkan manusia sebagai informasi dan komunikasi sehingga mempermudah manusia berkomunikasi satu sama lain dan memperoleh pengetahuan. Dengan adanya internet masyarakat dapat mengetahui dan up to date mendapatkan berita dari berbagai belahan dunia. Alasan mengambil tempat Penelitian Tugas Akhir (Skripsi) di Toko Faisal Elektronik 2 Elektronik adalah untuk menganalisa peranan teknologi informasi yang terdapat di Toko Faisal Elektronik 2 yang mengarah dibidang teknologi, adapun Tugas Akhir ini dilaksanakan pada bidang teknologi umum pada instansi tersebut. Dalam sebuah intansi saat ini, 
komputer merupakan sebuah alat atau sarana yang sangat membantu dalam menyelesaikan pekerjaan pertokoan dibidang masing-masing. Toko Faisal Elektronik 2 tempat saya melaksanakan Penelitian masih menggunakan sistem manual untuk penjualan dan pencatan. Hal ini tidak dapat dipungkiri lagi , karena dengan menggunakan komputer pekerjaan dapat selesai dengan cepat dan hasil yang sangat memuaskan. Sehubungan dengan hal itu, dibutuhkan web pada Toko Faisal Elektronik 2 untuk menyampaikan informasi ke calon pelanggan tentang profil Toko Faisal Elektronik 2, fasilitas, dan serta membuat para calon pelanggan Toko Faisal Elektronik 2 mudah untuk mengakses informasi-informasidan informasi tentang barang-barang Elektronik yang ada di Toko Faisal Elektronik 2. Dengan itu para calon pelanggan tertarik untuk membeli kompnenen Elektronik yang ada di Toko Faisal Elektronik 2.

\section{TINJAUAN PUSTAKA}

Sistem adalah kumpulan atau himpunan dari unsur atau variabel-variabel yang saling terkait, saling berinteraksi, dan saling tergantung satu sama lain untuk mencapai tujuan. Selain itu, sistem juga dapat didefinisikan sebagai sekumpulan objek-objek yang saling berelaksi dan berinteraksi, serta hubungan antar objek bisa dilihat sebagai satu kesatuan yang dirancang untuk mencapai satu tujuan yang telah ditetapkan [1].

Informasi merupakan hasil pengolahan data sehingga menjadi bentuk yang penting bagi penerimanya dan mempunyai kegunaan sebagai dasar dalam pengambilan keputusan yang dapat dirasakan akibatnya secaralangsung saat itu juga atau secara tidak langsung pada saat mendatang [2].

Sebuah sistem informasi merupakan kumpulan dari perangkat keras dan perangkat lunak komputer serta perangkat manusia yang akan mengolah data menggunakan perangkat keras dan perangkat lunak tersebut. Selain itu data juga memegang peranan penting dalam sistem informasi. Data yang akan dimasukkan adalah sebuah sistem informasi berupa formulir-formulir, prosedur-prosedur dan bentuk data lainnya [3].

Dalam pengembangan sistem informasi, salah satu model dinamakan siklus hidup pengembangan sistem (Systems Development Life Cycle/SDLC) yang memuat langkah-langkah yang semestinya diikuti dalam perancangan basis data dan pemrogram, untuk menspesifikasikan, mengembangkan, serta memelihara sistem informasi. Proses ini sering digambarkan secara bertingkat seperti yang diperlihatkan pada Gambar 1. Metafora bertingkat atau air terjun (waterfall) digunakan untuk menggambarkan bahwa keluaran dari suatu tahap merupakan masukan untuk tahap berikutnya. Walaupun demikian, seperti yang diperlihatkan di Gambar 1 proses ini tidak benar-benar berjalan secara linear, suatu tahap mungkin berjalan secara parallel serta dimungkinka untuk kembali pada langkah berikutnya (proses iterasi) saat suatu keputusan tertentu perlu dipertimbangkan lagi [4].



Gambar 1 Pengembangan sistem SDLC 
Unified Modelling Language (UML) adalah bahasa pemodelan untuk sistem atau perangkat lunak yang berparadigma berorientasi objek. Abstraksi konsep dasar UML terdiri dari structural classification, dynamic behavior, dan model management dapat kita pahami main concepts sebagai term yang akan muncul pada saat membuat diagram dan view adalah kategori dari diagram tersebut. UML mendefinisikan diagram-diagram sebagai Use case diagram, Class diagram, Statechart diagram, Activity diagram,Sequence diagram, Collaboration diagram, Component diagram, dan Deployment diagram [5].

Implementasi ini adalah untuk menyeselaikan desain sistem yang telah disetujui, menguji serta mendokumentasikan program - program dan prosedur sistem yang diperlukan, memastikan bahwa personil yang terlibat dapat mengoperasikan sistem yang baru dan memastikan bahwa konversi sistem lama ke sistem baru dapat berjalan dengan baik dan benar [6]. Pengertian aplikasi adalah satu unit perangkat lunak yang dibuat untuk melayani kebutuhan akan beberapa aktivitas [7].

Penjualan merupakan suatu kegiatan yang dilakukan sebagian manusia dalam menjual barang dagangan yang dimiliki baik itu barang ataupun jasa kepada pasar agar mencapai suatu tujuan yang diinginkan. Penjualan adalah suatu transaksi yang bertujuan untuk mendapatkan suatu keuntungan, dan merupakan suatu jantung dari suatu perusahaan, Dengan pengertian lain definisi penjualan adalah pemindahan hak milik atas barang atau pemberian jasa yang dilakukan penjualan kepada pembeli dengan harga yang disepakati bersama dengan jumlah yang dibebankan kepada pelanggan dalam penjualan barang atau jasa dalam suatu periode akuntansi [8].

Internet Interconnected Network atau yang lebih dikenal dengan sebutan internet adalah suatu jaringan komputer raksasa dengan daya jangkau yang mendunia. Pengertian lain internet (inter-network) merupakan jaringan yang menggabungkan beberapa komputer yang terhubung dalam sebuah internet protocol (IP) yang mencakup secara luas ke seluruh dunia [9].

Website (Situs Web) merupakan kumpulan dari halaman-halaman web yang berhubungan dengan file-file lain yang terkait. Dalam sebuah website terdapat suatu halaman yang dikenal dengan sebutan home page. Home page adalah sebuah halaman yang pertama kali dilihat ketika seseorang mengunjungi website. Dari home page, pengujung dapat mengklik hyperlink untuk pindah kehalaman lain yang terdapat dalam website tersebut [10].

Browsing adalah Berselancar untuk menjelajahi informasi yang ada di internet. Browsing dapat juga diartikan seni pencarian informasi melalui system operasi yang berbasis hypertext, misalnya membaca berita, mencari istilah dan lain-lain [11].

PHP kependekan dari Hypertext Preprocessor adalah salah satu bahasa pemrograman open source yang sangat cocok atau dikhususkan untuk pengembangan Web dan dapat di tanamkan pada sebuah skrip HTML. Bahasa PHP dapat dikatakan menggambarkan beberapa bahasa pemrograman seperti C, Java, dan Perl serta mudah untuk dipelajari [12].

Dreamwaver adalah sebuah HTML editor Profesional untuk mendesain web secara visual dan mengelola situs atau halaman web. Dreamwaver banyak digunakan oleh Web Desainer maupun Web Programmer dalam mengembangkan suatu situs web. Hal ini disebabkan ruang kerja, fasilitas, dan kemampuan Dreamwaver yang mampu meningkatkan produktivitas dan efektivitas dalam desain maupun dalam hal membangun suatu situs web [13].

MySQL adalah sebuah implementasi dari sistem manajemen basisdata relasional (RDBMS) yang didistribusikan secara gratis dibawah lisensi GPL (General Public License). Setiap pengguna dapat secara bebas menggunakan MySQL, Namun dengan batasan perangkat lunak tersebut tidak boleh dijadikan produk turunan yang bersifat komersial. MySQL sebenarnya merupakan turunan salah satu konsep utama dalam basisdata yang telah ada sebelumnya; SQL (Structured Query Language). SQL adalah sebuah konsep pengoperasian basisdata, terutama untuk pemilihan atau seleksi dan pemasukan data, yang memungkinkan pengoperasian data dikerjakan dengan mudah secara otomatis [14].

XAMPP merupakan merupakan paket php berbasis open source yang dikembangkan oleh sebuah komunitas Open Source. Dengan menggunakan XAMPP kita tidak perlu lagi melakukan 
penginstalan program yang lain karena semua kebutuhan telah disediakan oleh XAMPP. Beberapa pakat yang telah disediakan adalah Apache, MySql, Php, Filezila, dan Php my admin [15].

\section{Metode Penelitian}

Adapun metode penelitian yang digunakan oleh penyusun dalam penelitian ini adalah:

\subsection{Metode Pengumpulan Data}

Pengumpulan data adalah berbagai cara yang digunakan untuk mengumpulkan data, menghimpun, mengambil, atau menjaring data penelitian. Kita mengenal metode observasi, wawancara, angket, dll. Cara-cara ini dipilih bukan tanpa alasan. Pertimbangan utama adalah kemampuan cara yang dipilih dalam menggali informasi. Kadang hanya diperlukan satu cara. Namun, kadang cara tunggal dinilai kurang mampu menjaring data secara lengkap, sehingga dibutuhkan metode lain sebagai metode sekunder.

Observasi

Observasi yaitu suatu teknik pengumpulan data atau informasi yang dilakukan dengan cara mengadakan pengamatan langsung ke objek dan juga menganalisa sistem yang sedang berjalan.

Wawancara

Yaitu metode pengumpulan data yang dilakukan dengan cara Tanya jawab secara langsung kepada pihak pihak terkait tentang data-data yang berhubungan dengan tempat tersebut.

Literatur

Yaitu metode yang dilakukan dengan mempelajari buku-buku yang berkaitan dengan Aplikasi Penjualan Berbasis Web dengan maksud memperoleh data sebagai bahan dasar perbandingan dalam pembahasan dan sebagai landasan teori.

\subsection{Metode Pengembangan Sistem}

Metode pengembangan perangkat lunak dalam proyek ini adalah SDLC (system development live cycle), yaitu tahap feasability, analisis, design,Development, testing, implementasi danmaintenance.

\section{HASIL DAN PEMBAHASAN}

Selanjutnya hasil dan pembahasan dari tiga tahapan perancangan, implementasi dan pengujian sistem dijelaskan sebagai berikut:

\subsection{Analisa Dan Perancangan}

Analisa sistem dilakukan setelah tahapan identifikasi dan perencanaan sistem. Tahapan analisa sistem merupakan tahapan yang kritis dan sangat penting karena kesalahan ditahap ini akan menyebabkan kesalahan di tahap selanjutnya.

1. Use Case Diagram

Untuk mengetahui logika apa yang dikerjakan oleh pengguna sistem, maka dirancanglah sebuah diagram use case. Dengan diagram ini juga dapat diketahui fungsi yang digunakan oleh sistem yang sekarang. Use case diagram dapat dilihat pada Gambar 2 dibawah ini. 


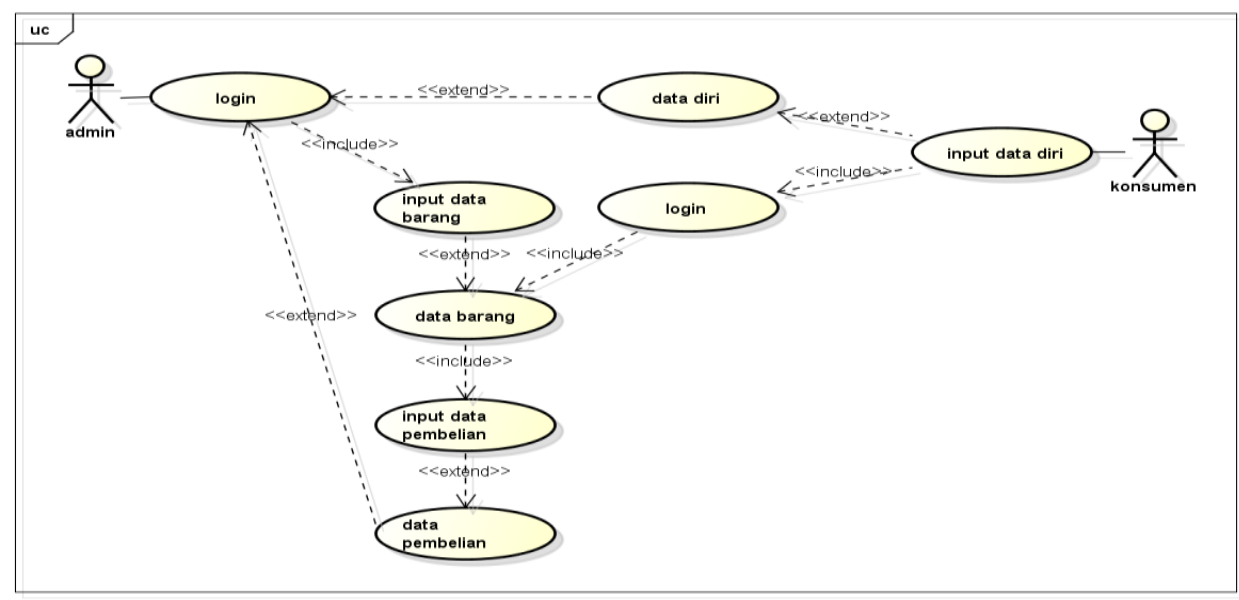

\section{Gambar 2 Use case diagram}

Skenario use case digunakan untuk memudahkan dalam menganalisa fase-fase yang akan dikerjalan selanjutnya. Adapun tahapan yang dapat dilakukan dalam sistem informasi toko online tersebut adalah untuk aktor admin setelah melakukan login, admin dapat menginputkan data barang. Untuk aktor konsumen setelah melakukan login, konsumen dapat melakukan pembelian barang. Dan admin juga dapat melihat data konsumen serta data pembelian.

\section{Sequence Diagram}

Sequence diagram data barang (konsumen) untuk sistem informasi penjualan pada Toko Faisal Elektronik 2 dapat dilihat pada Gambar 3 di bawah ini.

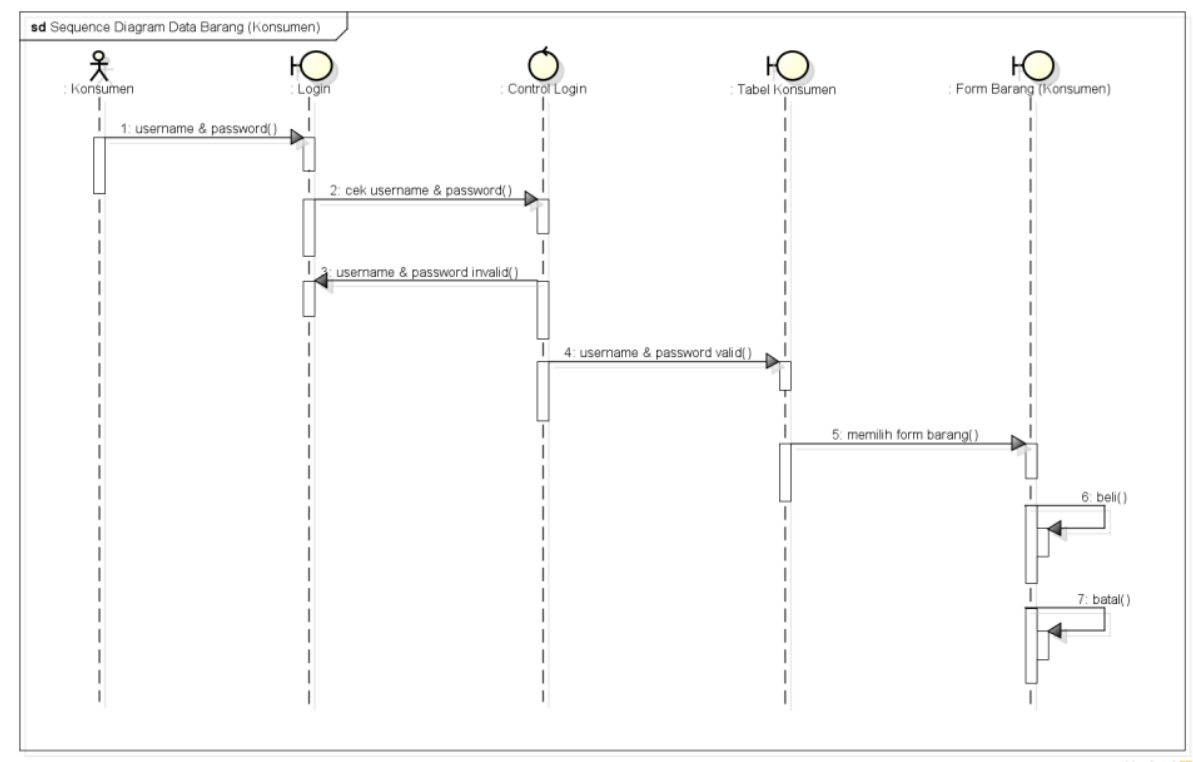

\section{Gambar 3 Sequence diagram data barang (Konsumen)}

Setelah konsumen login dengan username dan password yang benar, konsumen bisa memilih form barang jika ingin melakukan pembelian barang pada sistem tersebut. Di dalam form barang, konsumen dapat melakukan aksi seperti beli dan batal.

\section{Activity Diagram}

Activity diagram data barang (konsumen) untuk sistem informasi penjualan pada Toko Faisal Elektronik 2 dapat dilihat pada Gambar 4 di bawah ini. 


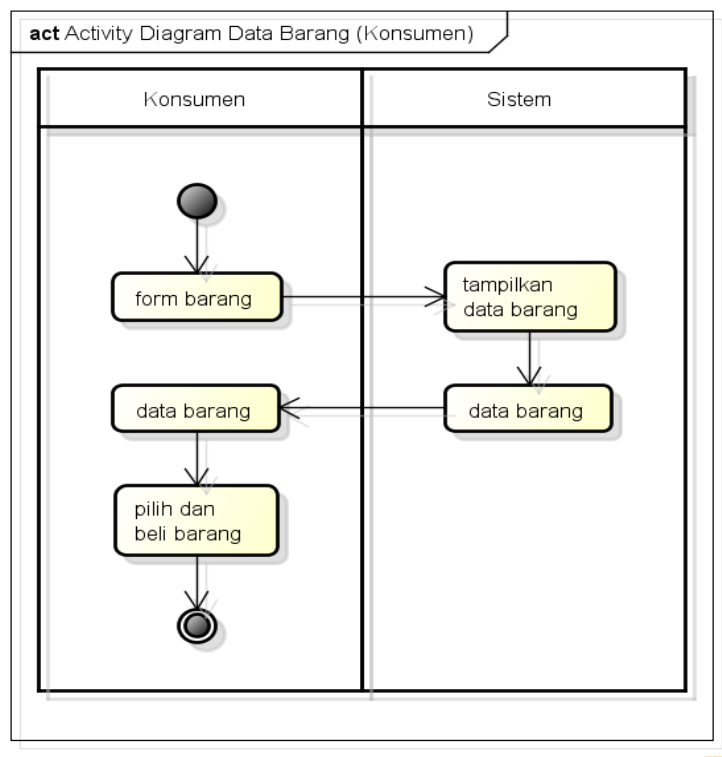

\section{Gambar 4 Activity diagram data barang (Konsumen)}

Dari gambar di atas, dapat dijelaskan bahwa saat konsumen ingin melakukan pembelian barang, konsumen dapat memilih form barang kemudian sistem akan menampilkan data barang, dan konsumen dapat memilih dan membeli barang yang diinginkan.

\section{Class Diagram}

Class diagram membantu kita dalam visualisasi struktur kelas-kelas dari suatu sistem dan merupakan tipe diagram yang paling banyak di pakai. Class diagram memperlihatkan hubungan antara kelas dan penjelasan detail tiap-tiap kelas di dalam model desain dari suatu sistem, seperti Gambar 5 berikut ini.

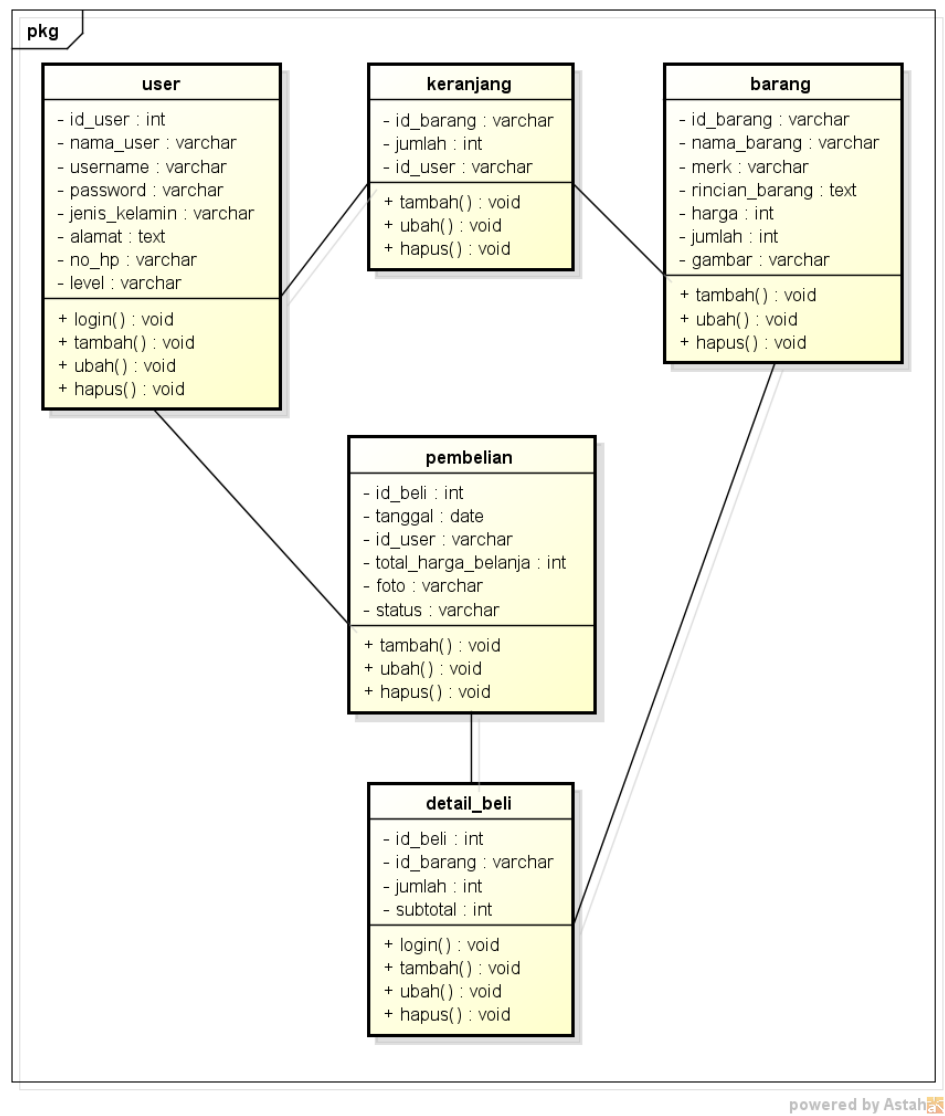

Gambar 5 Class diagram

Syriat, Sistem Informasi Penjualan Pada Toko Faisal Elektronik 2 Indragiri Hilir Berbasis WEB 
Dari tabel di atas dapat dijelaskan bahwa dalam pembuatan aplikasi penjualan pada Toko Faisal Elektronik 2 memiliki bebrapa database sebagai tempat penyimpanan datanya, yaitu tabel user, tabel barang, tabel keranjang, tabel pembelian, dan tabel detail_beli.

\subsection{Implementasi Sistem}

Implementasi merupakan tahapan penerapan dan pengoperasian sistem pada keadaan yang sebenarnya, sehingga akan diketahui apakah sistem yang telah dibangun benar-benar dapat berjalan dan sesuai dengan tujuan yang ingin dicapai. Setelah analisa dan perancangan sistem selesai, maka langkah selanjutnya yang akan dilakukan adalah implementasi atau penerapan sistem.

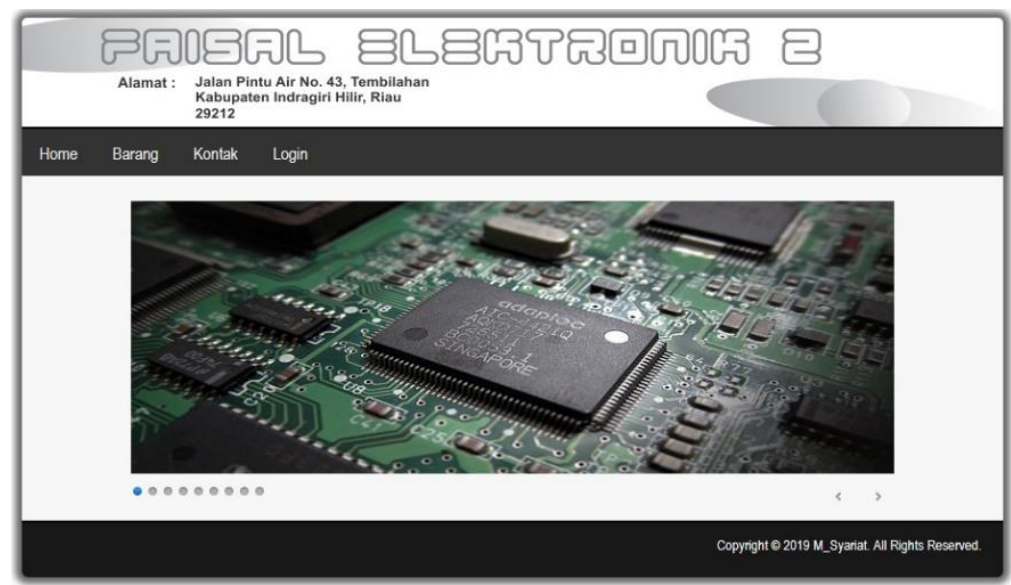

\section{Gambar 6 Tampilan awal sistem}

Gambar 6 di atas merupakan tampilan awal dari sistem informasi Toko Faisal Elektronik 2. Di dalam sistem informasi Toko Faisal Elektronik 2 ini terdapat beberapa menu diantaranya menu Home, Barang, Kontak, dan Login.

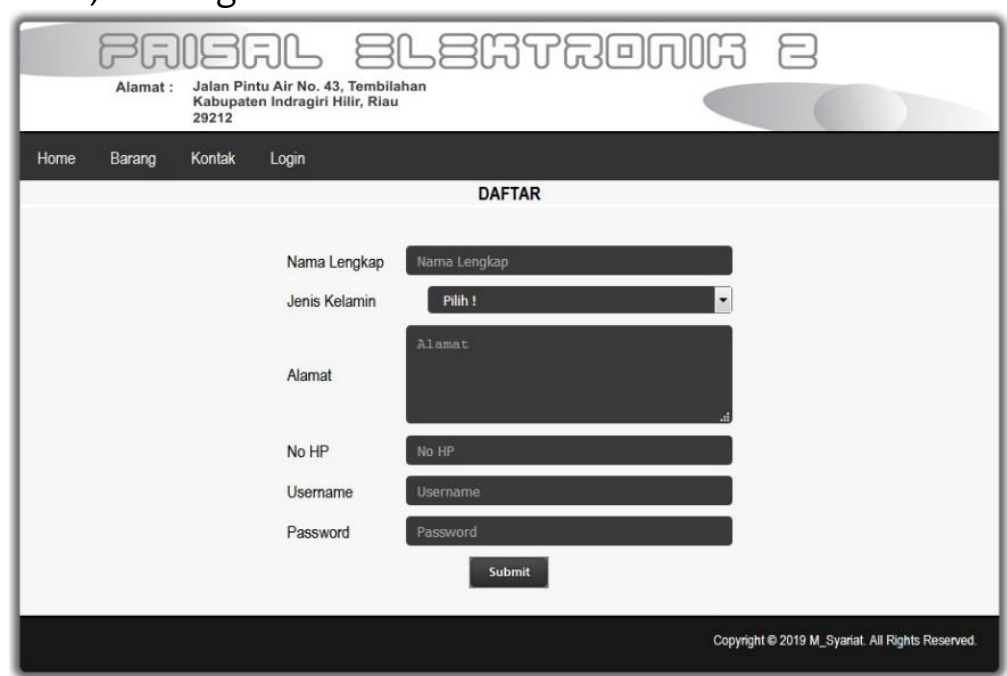

Gambar 7 Tampilan form daftar

Gambar 7 di atas merupakan tampilan form daftar, pada saat pengguna meng-klik link daftar yang berada pada halaman login, maka sistem akan membawa pengguna pada form daftar. Disini pengguna harus memasukkan Nama Lengkap, Jenis Kelamin, Alamat, No HP, Username dan Password. Setelah itu pengguna cukup meng-klik tombol Submit dan data pengguna akan disimpan ke dalam database dan pengguna bisa Login menggunakan Username dan Password yang telah di daftarkan tadi. 


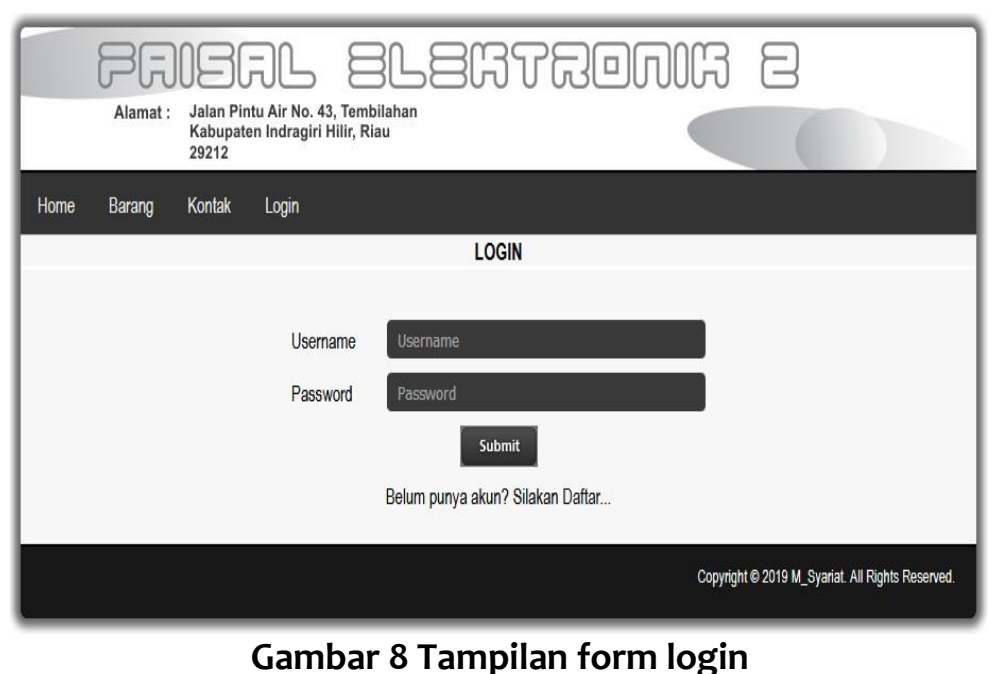

Gambar 8 di atas merupakan tampilan form Login, pada halaman Login pengguna yang telah mendaftarkan diri cukup memasukkan Username dan Password yang telah di daftarkan sebelumnya setelah itu cukup menekan tombol Submit, dan selanjutnya sistem akan membawa pengguna ke tampilan halaman awal User.

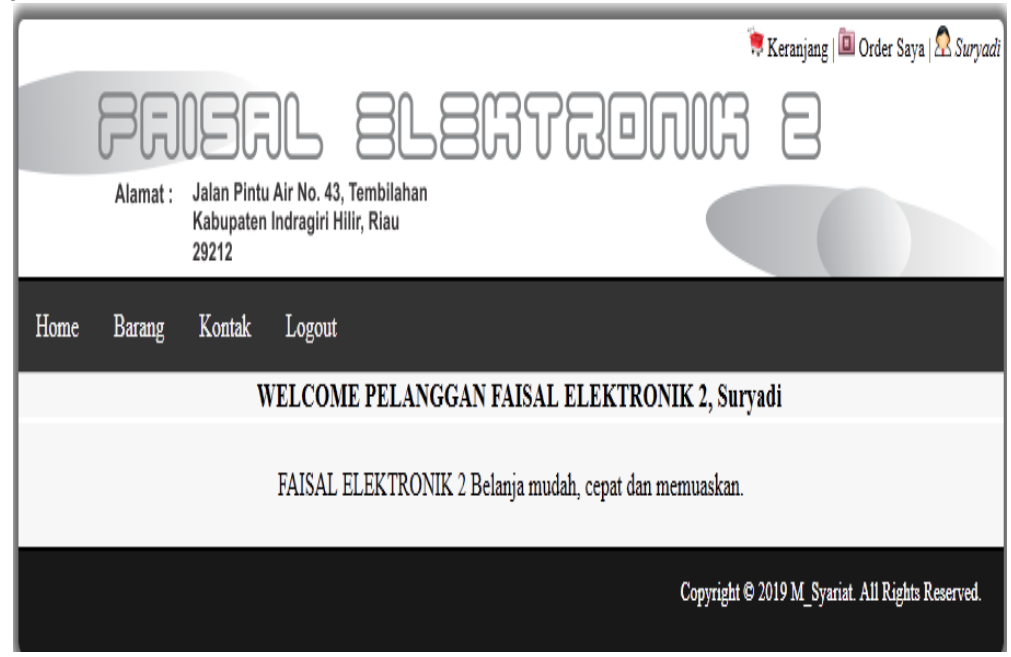

Gambar 9 Tampilan Halaman Awal User

Gambar 9 di atas merupakan tampilan halaman utama user, setelah pengguna Login, pengguna akan di arahkan ke dalam tampilan halaman awal user. Disinilah pengguna bisa membeli barang.

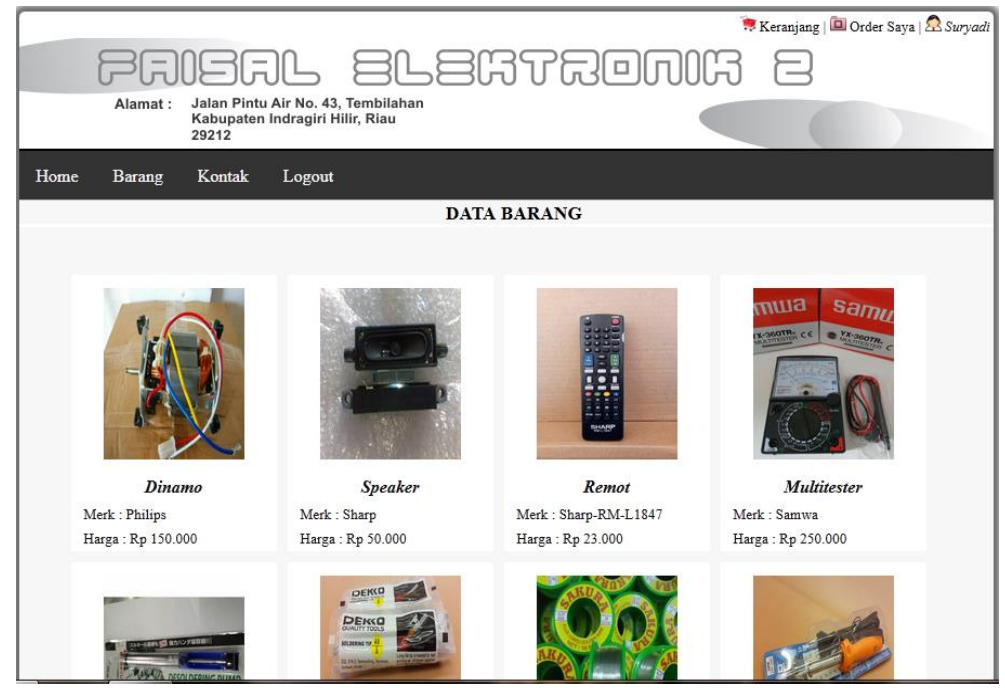

Gambar 10 Tampilan halaman barang

Syriat, Sistem Informasi Penjualan Pada Toko Faisal Elektronik 2 Indragiri Hilir Berbasis WEB 
Gambar 10 di atas merupakan tampilan data produk yang dijual oleh Toko Faisal Elektronik 2. Pengguna cukup meng-klik pada produk yang ingin di beli, dan selanjutnya sistem akan membawa ke tampilan rincian produk agar pengguna bisa membaca lebih lengkap tentang produk yang ingin dibeli.

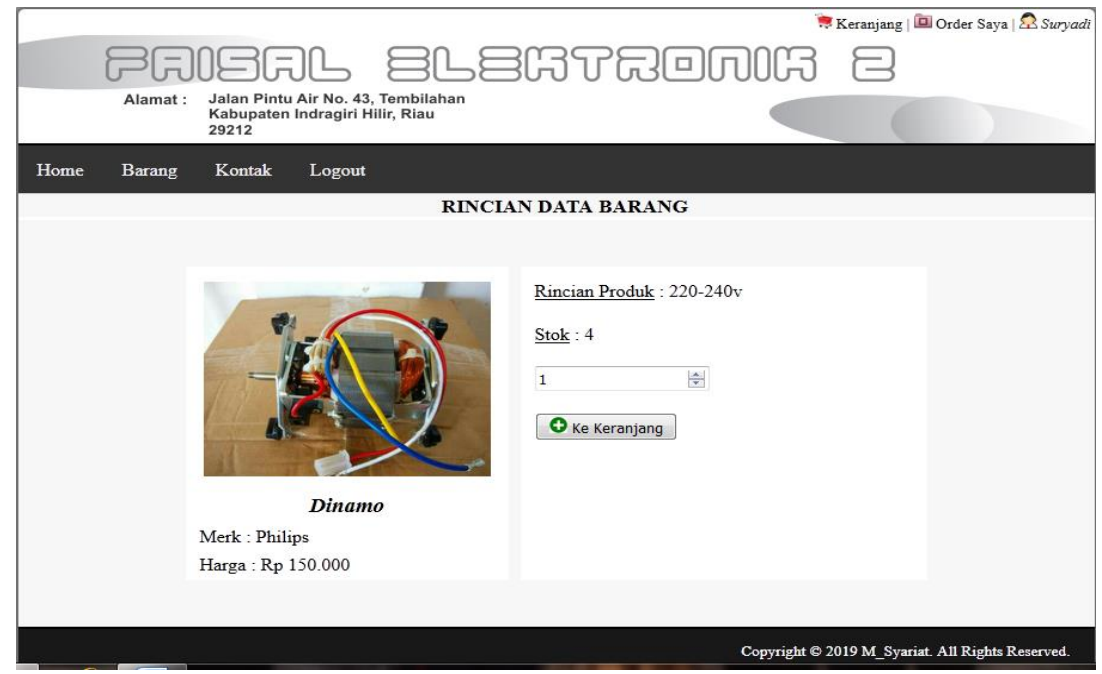

Gambar 11 Tampilan halaman rincian barang

Gambar 11 di atas merupakan tampilan rincian data produk. Sebelum pengguna ingin memasukkan barang barang yang akan dibeli ke keranjang, pengguna dapat melihat rincian barang yang ingin dibeli, dan setelah itu pengguna cukup memasukkan jumlah yang ingin dibeli dan setelah itu pengguna cukup menekan tombol "Ke Keranjang" dan barang yang ingin pengguna beli tersebut akan di masukkan ke keranjang pegguna.

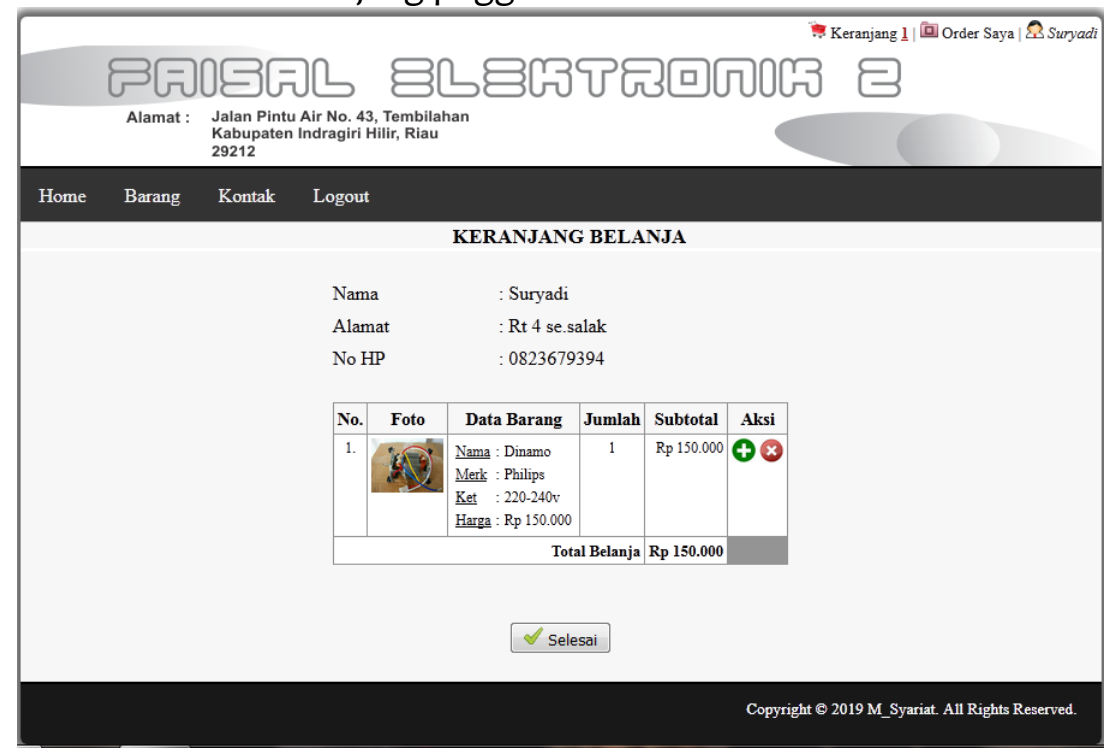

Gambar 12 Tampilan halaman keranjang

Gambar 12 di atas merupakan tampilan data barang yang sudah dimasukkan ke dalam keranjang pengguna. Sebelum pengguna membeli barang dan melakukan pembayaran, pengguna dapat melihat dulu barang apa saja yang telah dimasukkan ke keranjang beli. Disini pengguna dapat menambah jumlah barang yang ingin dibeli dan juga pengguna dapat menghapus barang yang sudah dimasukkan ke keranjang jika tidak jadi membelinya. Disini juga telah tersedia total harga dan total yang harus dibayar oleh pengguna. Setelah semuanya benar dan pengguna ingin membeli, pengguna cukup menekan "Selesai" yang berarti pengguna telah memesan dan pengguna harus melakukan pembayaran dalam $3 \times 24$ jam, atau pesanan pengguna tadi akan dibatalkan otomatis oleh sistem. 


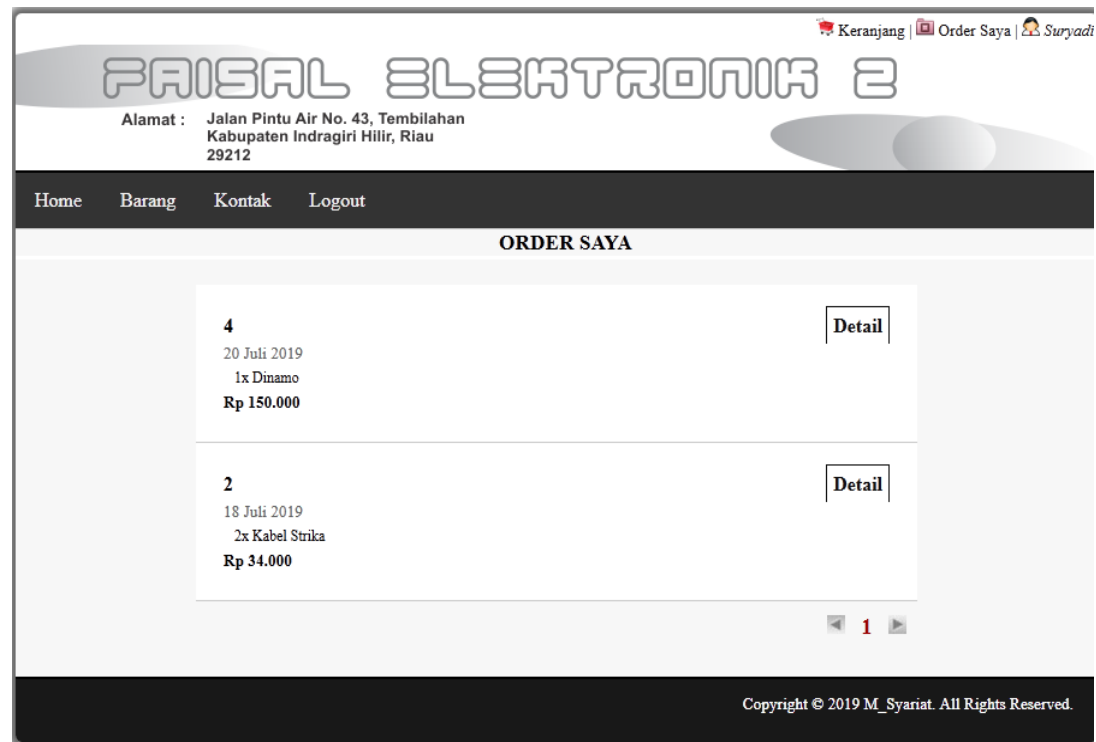

\section{Gambar 13 Tampilan Halaman Order Pengguna}

Gambar 13 di atas merupakan tampilan data order pengguna. Disini pengguna dapat melihat semua data pesanan yang telah dilakukan oleh pengguna itu sendiri. Dan untuk melihat detailnya, pengguna cukup meng-klik link "Detail” disebelah kanan tampilan data.

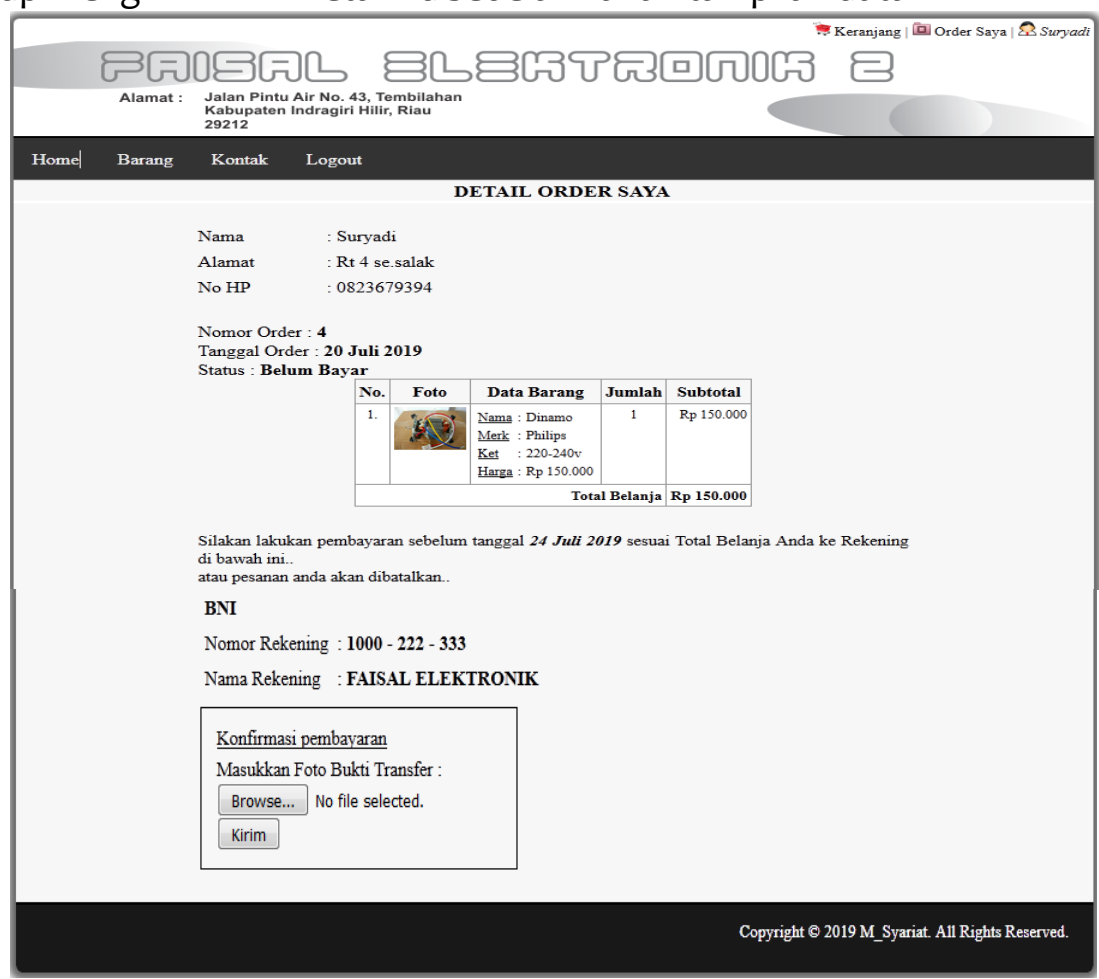

Gambar 14 Tampilan Halaman Detail Pesanan

Gambar 14 di atas merupakan tampilan lengkap dari pesanan yang telah dilakukan oleh pengguna. Disini juga tempat pengguna meng-upload bukti transfer atau bukti pembayaran yang telah dilakukan agar barang dapat dikirim oleh Toko. Setelah meng-upload bukti pembayaran disini, pengguna cukup menunggu barang yang tadi dipesan sampai ke tangan pengguna. 


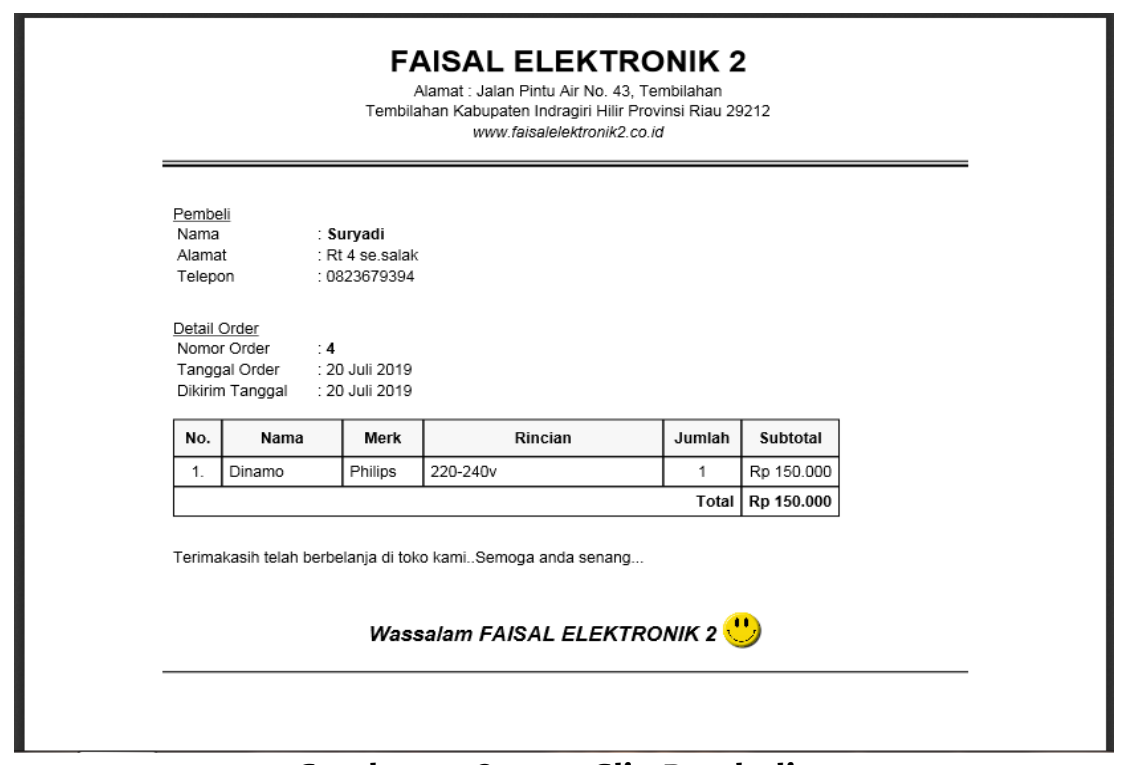

Gambar 15 Output Slip Pembelian

Gambar 15 di atas merupakan tampilan dari slip pembelian barang yang telah dilakukan oleh User dan dicetak oleh Admin dari website Toko Faisal Elektronik 2. Bukti slip pembelian ini akan dikirim dengan barang yang telah di order oleh pengguna.

\section{KESIMPULAN}

Beberapa hal yang dapat disimpulkan dari penelitian ini adalah sebagai berikut: (1). Dengan adanya sistem informasi penjualan pada Toko Faisal Elektronik 2 ini, dapat memberikan informasi barang yang dijual melalui website, Sehingga para konsumen tidak harus lagi datang ke toko dan mempromosikan barang secara luas tanpa ada batasan; (2). Dengan adanya sistem informasi penjualan pada Toko Faisal Elektronik 2 ini, dapat membantu memudahkan karyawan toko dalam melakukan pengolahan data transaksi serta pembuatan laporan; (3). Dengan adanya sistem informasi penjualan pada Toko Faisal Elektronik 2 ini, dapat memberikan kemudahan kepada para konsumen dalam mendapatkan informasi barang dan membeli barang.

Saran-saran yang dianggap perlu dikemukakan untuk pengembangan sistem informasi Toko Faisal Elektronik 2 antara lain: (1). Diharapkan dapat mengenalkan sistem informasi ini ke masyarakat secara lebih luas, sehingga mereka dapat merasakan mudahnya bertransaksi secara online di website ini; (2). Diharapkan kedepannya bisa merancang sistem informasi E-Commerce ini dengan menggunakan bahasa pemrograman lainnya.

\section{REFERENSI}

[1]. Tohari, H. (20014). Astah- Analisa serta Perancangan Sistem Informasi melalui Pendekatan UML. Yogyakarta: Andi.

[2]. Sutanta, Edhy, Sistem Basis Data.Penerbit Graha Ilmu, Yogyakarta, 2004

[3]. Kristanto, A. (2008). Perancangan Sistem Informasi dan Aplikasinya. Yogyakarta: Gava Media.

[4]. Nugroho, A. (2011). Perancangan dan Impelementasi Sistem Basis Data . Yogyakarta: Andi.

[5]. Suendri, (2018). Implementasi Diagram UML (Unified Modelling Language) Pada Perancangan Sistem Informasi Remunerasi Dosen Dengan Database Oracle Studi Kasus: UIN Sumatera Utara Medan). Jurnal Ilmu Komputer dan Informatika

[6]. Syachbana. (2011). Sistem Informasi Akademik Berbasis Multimedia Pada Lembaga Pendidikan Palembang Technology.

[7]. Septi, L., \& Sari Shinta Wellia, M. (2015). Perancangan Aplikasi Mobile E-Commerce Berbasis Android Pada Violet Fashion Jepara. 
[8]. Andri Prasetyo, R. S. (2016). Sistem Informasi Penjualan Berbasis Web Pada PT. Cahaya Sejahtera Sentosa Blitar. Jurnal Ilmiah Teknologi dan Informasi ASIA (JITIKA), 1.

[9]. Syafrudin, S.T. dan Eko. 2008. Koneksi Internet untuk PC, Laptop dan HP. Yogyakarta : MediaKom

[10]. B. E. P. I. U. W. Rulia Puji Hastanti1, "sistem penjualan berbasis web (e-commerce) pada Tato Distro Kabupaten Pacitan,” Indian J. Pure Appl. Math., vol. 49, no. 3, pp. 549-557, 2018.

[11]. Adiyanto, Suraya, \& Sutanta, E. (2013).INTEGRASI APLIKASI WEB DAN SMS GATEWAY PADA TPI GEMPOLSARI MENGGUNAKAN PHP DAN MYSQL. Jurnal JARKOM, 49-56.

[12]. Aspriyono, H., \& Jauhari. (t.thn.). Sistem Pelayanan Online pada SD Negeri 62 Kota Bengkulu Menggunakan Adobe Dreamweaver CS4.

[13]. Heni A. Puspitosar,i 2010, Having Fun With Adobe Dreamweaver CS4: Andi \& Wahana. Yogyakarta.

[14]. Februariyanti, H. (2012). Rancang Bangun Sistem Perpustakaan untuk Jurnal Elektronik. Jurnal Teknonogi Informasi DINAMIK, 124-132.

[15]. Nugroho, Bunafit, Latihan Membuat Aplikasi Web PHP dan MySQL dengan Dreamweaver MX $(6,7,2004)$ dan 8, Penerbit GAVA MEDIA, Yogyakarta,2008 